\title{
Ketosis in Hepatic Glycogenosis
}

\author{
J. FERNANDES^ and N. A. PIKAAR \\ From the Department of Paediatrics, The University, Utrecht, and Central Institute for Nutrition and Food Research, \\ Zeist, The Netherlands
}

Fernandes, J., and Pikaar, N. A. (1972). Archives of Disease in Childhood, 47, 41. Ketosis in hepatic glycogenosis. The occurrence of ketosis in 41 patients with liver glycogenosis and a control group of 22 children was investigated. Fasting ketosis was present in children with a deficiency of the debranching enzyme system and in young children with a deficiency of the phosphorylase system, but never in patients with a glucose-6-phosphatase deficiency.

Oral tolerance tests on a patient deficient in debranching enzyme showed that the blood levels of glucose and ketone bodies changed in the opposite direction. It is argued that, for biochemical reasons, the occurrence of ketosis in patients with a glucose-6-phosphatase deficiency is improbable.

Ketosis has generally been considered to be a characteristic feature of glycogen storage disease in childhood (van Creveld, 1928, 1932; Howell, Ashton, and Wyngaarden, 1962; Hug and Schubert, 1967; Kelsch and Oliver, 1969; Lowe et al., 1962; Rennert and Mukhopadhyay, 1968; Sidbury, Gitzelmann, and Fisher, 1961; Sokal et al., 1961).

While studying some aspects of the carbohydrate and fat metabolism of children with glycogenosis of the liver (Fernandes and van de Kamer, 1965; Fernandes and Pikaar, 1969), we were puzzled by the fact that, though we frequently encountered fasting ketosis in our debranching enzyme- and phosphorylase-deficient patients, we never saw it in our patients with glucose-6-phosphatase deficiency.

The normal fasting levels of ketone bodies in the blood of the latter seemed the more unexpected as they have the strongest tendency towards hypoglycaemia of all types of glycogenosis patients, and it is known that hypoglycaemia causes a rise of the free fatty acid concentration in the plasma. Thus, under hypoglycaemic conditions one might expect an enhanced rate of fatty acid oxidation and ketone body synthesis in the liver to compensate for the deficient glucose supply. Therefore, in glucose-6phosphatase deficiency even more than in other types of glycogenosis, ketosis would be expected to occur frequently. Indeed, many authors implicitly assume, or even explicitly state, this to be the case

\footnotetext{
Received 29 July 1971.

^Present address: Sophia Children's Hospital and Neonatal Unit, Rotterdam Medical School, Rotterdam, The Netherlands.
}

(Howell et al., 1962; Hug and Schubert, 1967; Kelsch and Oliver, 1969; Rennert and Mukhopadhyay, 1968). Because of the conflicting evidence we decided to gather more data on ketosis in patients with the three most common types of glycogenosis, e.g. glucose-6-phosphatase deficiency, deficiency of the debranching enzyme system, and deficiency of the phosphorylase system.

\section{Patients and Methods}

The investigation comprised 41 patients and 22 normal children. The relevant clinical and biochemical data of the patients are presented in Tables I-III. The patients with a glucose-6-phosphatase deficiency were diagnosed by enzymic assay of a liver biopsy (Table I). The patients with a deficiency of the debranching enzyme system were diagnosed by enzymic assay of the leucocytes: in three of them an enzymic assay of a liver

\section{TABLE I}

Enzyme Assays in 5 Children with Glucose-6phosphatase Deficiency

\begin{tabular}{c|c}
\hline Case No. & Glucose-6-phosphatase in Liver \\
\hline 1 & $0 \cdot 07^{\star}$ \\
2 & $0 \cdot 00^{\star}$ \\
3 & $0 \cdot 08^{\star}$ \\
5 & $0 \cdot 00 \dagger^{\prime}$ \\
& $0 \cdot 00 \dagger$ \\
\hline
\end{tabular}

${ }^{*} \mu$ moles $P_{1} / \min$ per $g$ tissue (Hers, 1964), normal range 2-10. Enzyme assays by Professor H. G. Hers (Louvain).

tumoles $P_{i} /$ min per $\mathrm{mg}$ protein measured on the total homogenate (Harper, 1962), normal range 5.9-93 $(\mathrm{N}=7)$. Enzyme assays by Dr. J. F. Koster (Rotterdam). 
TABLE II

Enzyme Assays of 7 Children with Deficiency of Debranching Enzyme System

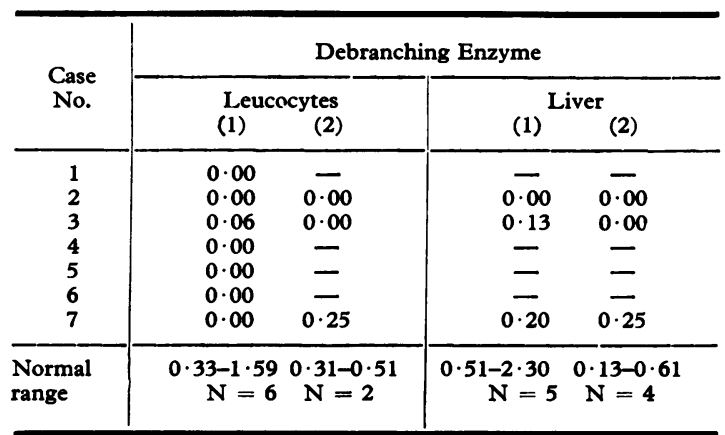

(1) nmoles glucose produced from phosphorylase limit dextrin/ min per $\mathrm{mg}$ protein (Huijing, 1964).

(2) nmoles glucose incorporated/min per mg protein (Hers, 1964). The enzyme assays were performed by Dr. J. H. van de Kamer (Utrecht), Dr. J. F. Koster (Rotterdam), or Professor H. G. Hers (Louvain).

biopsy was performed as well (Table II). The patients with a deficiency of the phosphorylase system were diagnosed by enzymic assay of the leucocytes (Table III). These patients, Cases 1 and 8 excepted, belong to the phosphorylase kinase-deficient type (Huijing, 1967); most belong to two large pedigrees (Huijing and Fernandes, 1969).

The finding of a deficiency of phosphorylase kinase in the leucocytes was confirmed by enzymic assay of a liver biopsy in Cases 2, 15, and 27.

The ketone bodies, acetone, 3-ketobutyrate, and 3hydroxybutyrate were estimated separately in capillary blood. The method of Peden (1964) was used in a scaled-down version. The results were the same as with the original method.

Glucose was estimated with glucose oxidase (reagent set TC-M of Boehringer and Soehne, Mannheim, West Germany), and nonesterified fatty acids (NEFA) were estimated with a micromodification of Dole's method (Fernandes and van de Kamer, 1965; Trout, Estes, and Friedberg, 1960).

As regards the procedure of the oral tolerance tests, $2 \mathrm{~g}$ glucose or casein per $\mathrm{kg}$ body weight was administered as a $10 \%$ solution.

\section{Results}

General survey. Fig. 1 represents the fasting blood levels of total ketone bodies in patients with different types of liver glycogenosis and controls. The preceding fasting period was 8 to 14 hours except for one infant with a glucose-6-phosphatase deficiency whose tendency towards hypoglycaemia did not permit a fast longer than 4 to 6 hours. A striking ketosis was present in most children with a debranching enzyme deficiency and several children with a phosphorylase deficiency, but not
TABLE III

Enzyme Assays of 29 Children with Deficiency of Phosphorylase System

\begin{tabular}{|c|c|c|c|}
\hline $\begin{array}{l}\text { Case } \\
\text { No. }\end{array}$ & $\begin{array}{c}\text { Phosphorylase b } \\
\text { Kinase in } \\
\text { Leucocytes (1) }\end{array}$ & $\begin{array}{l}\text { Phosphorylase in } \\
\text { Leucocytes (2) } \\
\text { - AMP + AMP }\end{array}$ & $\begin{array}{c}\text { Phosphorylase } \\
\text { b Kinase } \\
\text { in Liver (1) }\end{array}$ \\
\hline $\begin{array}{r}1 \\
2 \\
3 \\
4 \\
5 \\
6 \\
7 \\
8 \\
9 \\
10 \\
11 \\
12 \\
13 \\
14 \\
15 \\
16 \\
17 \\
18 \\
19 \\
20 \\
21 \\
22 \\
23 \\
24 \\
25 \\
26 \\
27 \\
28 \\
29\end{array}$ & $\begin{array}{l}0.57 \\
0.11 \\
0.11 \\
0.09 \\
0.08 \\
0.10 \\
0.08 \\
0.41 ; 0.55 \\
0.04 \\
0.07 \\
0.08 \\
0.08 \\
0.06 \\
0.00 \\
0.04 \\
0.09 \\
0.07 \\
0.12 \\
0.11 \\
0.16 \\
0.09 \\
0.02 \\
0.09 \\
0.02 \\
0.07 \\
0.08 \\
0.12 \\
0.10 \\
0.05\end{array}$ & 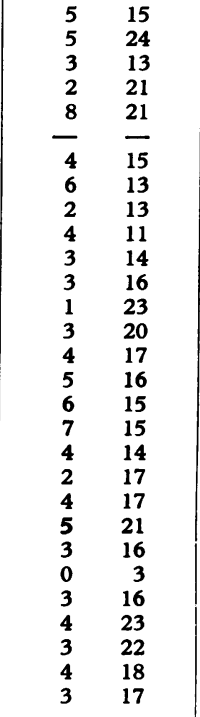 & 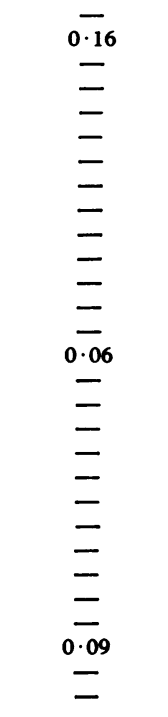 \\
\hline Normal & $\begin{array}{c}0.56 \pm 0.19 \\
(\text { Mean } \pm S D) \\
N=58\end{array}$ & $\begin{array}{c}19 \pm 624 \pm 6 \\
(\text { Mean }+S D) \\
N=39 N=39\end{array}$ & $\begin{array}{c}0.27-0.98 \\
\text { (Range) } \\
N==5\end{array}$ \\
\hline
\end{tabular}

(1) Units phosphorylase $\mathrm{b}$ activated/min per $\mathrm{mg}$ protein (Huijing 1967).

(2) nmoles glucose-1-phosphate produced from soluble starch/min per $\mathrm{mg}$ protein (Huijing, 1967). The enzyme assays in the leucocytes were performed by Dr. F. Huijing (Miami), those in the live by Dr. J. F. Koster (Rotterdam).

Dr. F. Huijing kindly gave advice on the adaptation of his method of phosphorylase kinase assay in leucocytes to liver biopsies.

in patients with a glucose-6-phosphatase deficiency. The fasting ketone body level in the phosphorylasedeficient patients is age-dependent (Fig. 2): the tendency towards ketosis declines with age to disappear around the age of 7 .

Additional experiments. After oral glucose administration to a patient with a debranching enzyme deficiency, the fasting ketosis disappeared completely (Fig. 3A). The administration of galactose or fructose to the same patient had an equally favourable effect (data not shown). Oral casein administration to this patient was followed by only slight decrease in the ketosis (Fig. 3B).

In the same child with a debranching enzyme deficiency, ketone body concentrations were estimated during prolonged fasting. Before the test, 


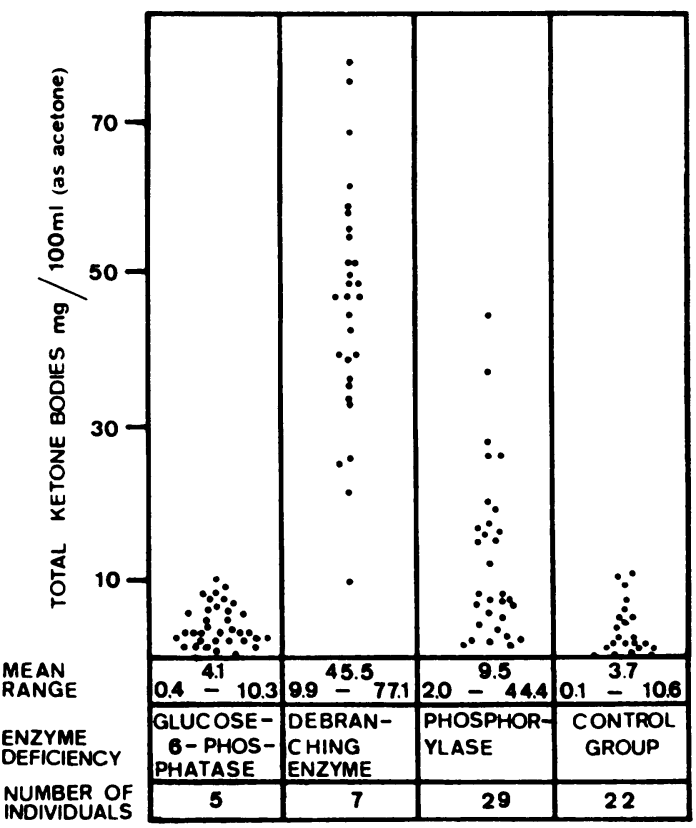

FIG. 1.-Total fasting ketone bodies in patients with different types of liver glycogenosis and controls.

this girl was fed every 3 hours during the night. Then she was fasted for 12 hours, during which period blood samples were taken at 2-hour intervals. A pronounced ketosis was already present 6 hours after the last meal (Fig. 4).

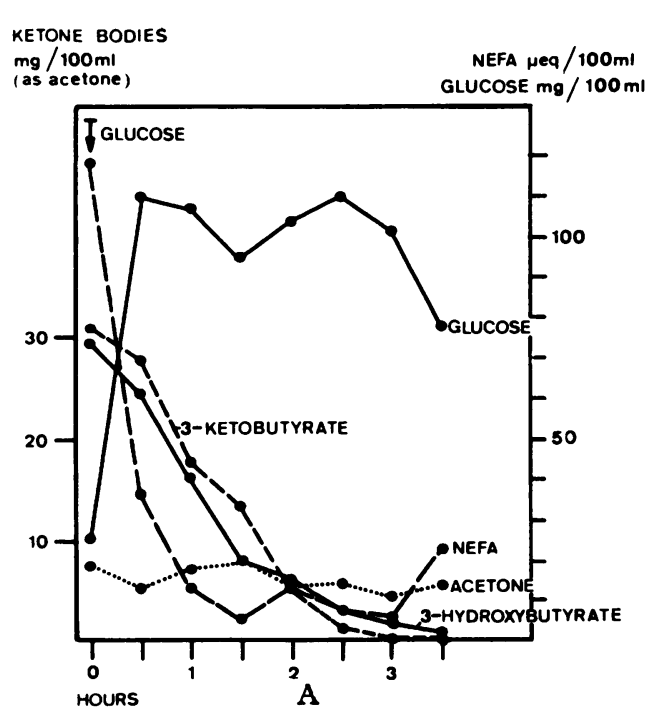

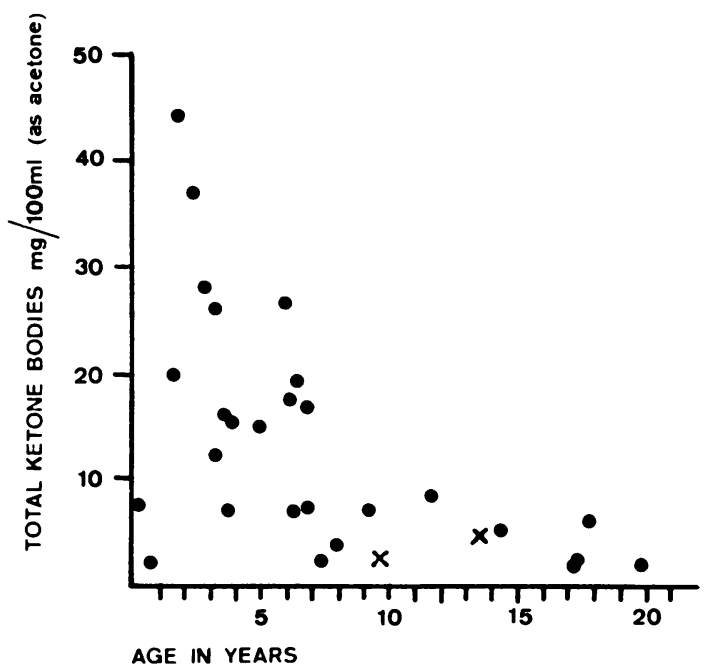

FIG. 2.-Correlation with age of total fasting ketone bodies in 27 patients with a phosphorylase kinase deficiency, (O), and 2 patients with a phosphorylase deficiency (x). Each patient is represented by one symbol.

\section{Discussion}

Our data indicate that ketosis is not characteristic of all forms of hepatic glycogenosis as we never encountered ketosis in our patients with glucose6-phosphatase deficiency (Fig. 1). This is in disagreement with the findings of several authors (Howell et al., 1962; Hug and Schubert, 1967;

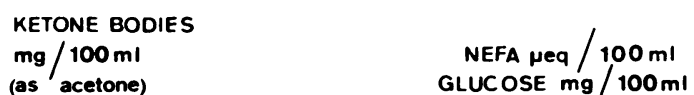

(as acetone) GLUCOSE $\mathrm{mg} / 100 \mathrm{ml}$

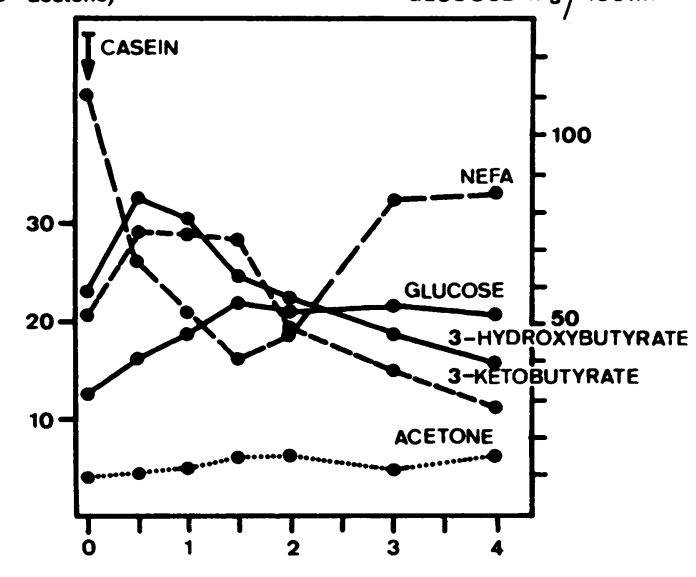

B

FIG. 3.-Ketone body concentrations during an oral glucose tolerance test $(A)$, and an oral casein tolerance test (B) in a child with a debranching enzyme deficiency (Case 3, Table II). 


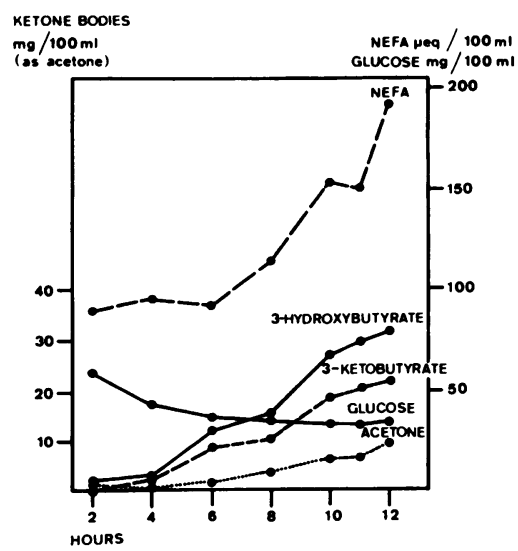

Fig. 4.-Ketone body concentrations during a 12-hour fasting period in a child with a debranching enzyme deficiency (Case 3, Table II).

Kelsch and Oliver, 1969; Rennert and Mukhopadhyay, 1968), though Field (1966) states that 'acetonuria and acetonaemia are inconsistently present', and 'several cases have been seen in which life-threatening acidosis supervened without the appearance of significant acetonaemia and acetonuria'.

Only a few authors have reported ketone body levels in the blood of their patients. Of these, Howell et al. (1962) report that their patients with glucose-6-phosphatase deficiency had raised levels (determinations performed by Sidbury), but Matschke et al. (1969) and Neubaur et al. (1969) report normal levels in their patients. In one publication (Brante, Kaijser, and Öckerman, 1964) the alleged occurrence of ketonuria in patients with glucose-6-phosphatase deficiency is not wholly substantiated by the simultaneously published laboratory data which agree with our data.

Thus, most of the factual evidence indicates that fasting ketosis does not normally occur in patients with glucose-6-phosphatase deficiency. Why, then, do most authors assume that ketosis does occur in these patients? We think there is an historical reason. The first glycogenosis patient on record (van Creveld, 1928, 1932, 1961) had a daily renal acetone excretion far higher than the sum of acetone and 3-ketobutyrate which we determined in 27 portions of 24-hour urine, collected from 4 patients with a glucose-6-phosphatase deficiency, that is $0 \cdot 15-4.05 \mathrm{mg} / 100 \mathrm{ml}$.

This first patient was originally characterized as 'un cas d'hypoglycémie avec acetonémie chez un enfant' (Snapper and van Creveld, 1928). Later, this patient was tentatively identified as a case of glucose-6-phosphatase deficiency, but in 1964 van Creveld and Huijing reported that enzyme assay in the leucocytes had unequivocally established the patient, then 44 years old, to have a debranching enzyme deficiency. The striking ketosis of this 'historical' patient may explain why ketosis is widely supposed to be a characteristic feature of all types of hepatic glycogenosis.

In retrospect it is not surprising that ketosis occurs only in the patients with a debranching enzyme or phosphorylase deficiency and not in those with a glucose-6-phosphatase deficiency, since there is a profound metabolic difference between the two former types and the latter type, as illustrated in Fig. 5.

In fasting patients deficient in debranching enzyme or phosphorylase, the formation of glucose6-phosphate from glycogen is blocked, and conse-

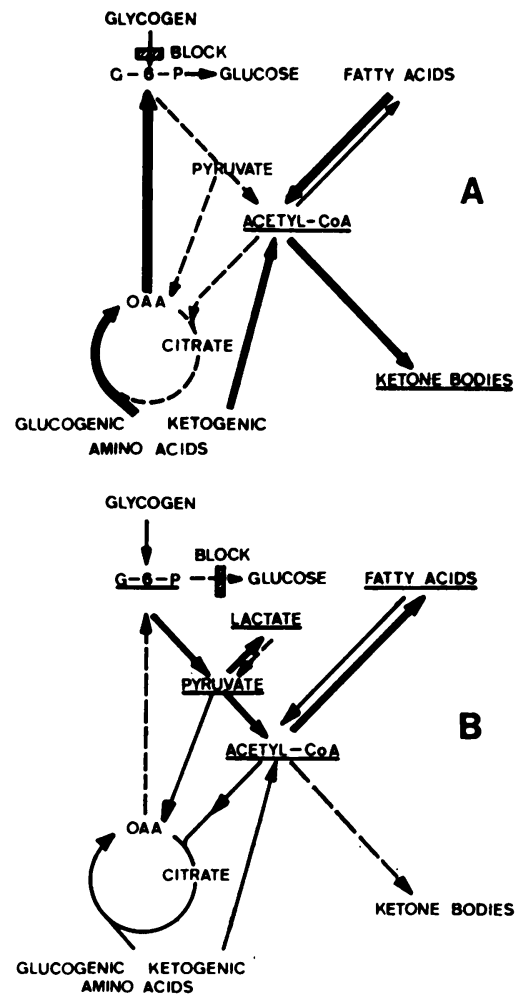

FIG. 5.-The effects of $(A)$ debranching enzyme and phosphorylase deficiency, and (B) glucose-6-phosphatase deficiency on the major metabolic pathways involved in ketogenesis and gluconeogenesis in the liver during fasting. Dashed arrows: depressed pathways; thick arrows: enhanced pathways; underlined: accumulating products. G-6-P: glucose-6-phosphate OAA: oxaloacetate. 
quently there is neither release of glucose into the circulation from this source, nor is there glycolysis owing to the lack of glucose-6-phosphate in the liver (Fig. 5A). These patients, like diabetics, presumably compensate for the deficient glucose supply by gluconeogenesis from protein in the liver. This constitutes a heavy drain on glucogenic amino acids and citric acid cycle intermediates, such as oxaloacetate. Fatty acid oxidation is increased at the same time, but the lack of oxaloacetate impedes the channelling of acetyl-CoA originating from fatty acid oxidation into the citric acid cycle (Shapiro, 1967).

The excess acetyl-CoA is converted into 3ketobutyryl-CoA, and thence into ketone bodies. Thus, by virtue of increased gluconeogenesis and fatty acid oxidation, ketosis ensues. By feeding carbohydrate gluconeogenesis in the liver is replaced by glycolysis, the oxaloacetate pool is rapidly replenished, and the citric acid cycle is restored to its full functional capacity, so that the ketosis disappears (Fig. 3A).

This explains the opposite course of the blood levels of glucose and ketone bodies in the debranching enzyme-deficient patient when glucose is administered (Fig. 3A) or feeding is withheld (Fig. 4). Protein naturally is not nearly as effective in the suppression of ketosis (Fig. 3B).

In fasting patients deficient in glucose-6phosphatase, on the other hand, the production of glucose-6-phosphate from glycogen is normal, whereas glucose liberation is blocked (Fig. 5B). These patients have an enhanced rate of glycolysis and an increased production of pyruvate and NADH. This favours the production of lactate, which partially replaces glucose as a metabolic substrate (Fernandes and Pikaar, 1969).

On account of the high pyruvate levels sufficient oxaloacetate synthesis can be expected. Thus, citric acid formation is not hampered by lack of oxaloacetate, no acetyl-CoA can possibly accumulate, and no overproduction of ketone bodies occurs (Havel et al., 1969). Moreover, the increased glycolysis during fasting not only furnishes pyruvate, but also the glycolytic intermediate dihydroxyacetone phosphate. Some of this compound is reduced by NADH in the glycerolphosphate dehydrogenase reaction to glycerol-1-phosphate. Since glycerol-1-phosphate is an acceptor for acyl$\mathrm{CoA}$ in the Kennedy pathway of triglyceride synthesis, less acyl-CoA may be available for $\beta$ oxidation. In summary, in glucose-6-phosphatase deficiency fatty acid oxidation is limited and excess ketone body production does not occur by virtue of the existence of glycolysis during fasting. In debranching enzyme or phosphorylase deficiency however, no glycolysis occurs in the fasting state, whereas fatty acid oxidation and ketone body production prevail. When glucose is supplied glycolysis occurs again and fatty acid oxidation and ketone body formation come to a stop.

We are indebted to Dr. R. N. Campagne, Biochemical Department, the University, Groningen, for his help in preparing the manuscript.

\section{REFERENCES}

Brante, G., Kaijser, K., and Ockerman, P. A. (1964). Glycogenosis type I (lack of glucose-6-phosphatase) in four siblings. Acta Paediatrica, 53, Suppl. 157.

van Creveld, S. (1928). Over een bijzondere stoornis in de koolhydraatstofwisseling in de kinderleeftijd. Nederlandsch Maandschrift Voor Geneeskunde, 75, 349.

van Creveld, S. (1932). Chronische hepatogene Hypoglykämie im Kindesalter. Zeitschrift für Kinderheilkunde, 52, 299.

van Creveld, S. (1961). Clinical course of glycogen disease. Chemisch Weekblad, 57, 453.

van Creveld, S., and Huijing, F. (1964). Differential diagnosis of the type of glycogen disease in two adult patients with long history of glycogenosis. Metabolism: Clinical and Experimental, $13,191$.

Fernandes, J., and van de Kamer, J. H. (1965). Studies on the utilization of hexoses in liver glycogen disease. Pediatrics, 35, 470.

Fernandes, J., and Pikaar, N. A. (1969). Hyperlipemia in children with liver glycogen disease. American fournal of Clinical Nutrition, 22, 617.

Field, R. A. (1966). Glycogen deposition diseases. In The Metabolic Basis of Inherited Disease, 2nd ed., p. 141. Ed. by J. B. Stanbury, J. B. Wyngaarden, and D. S. Fredrickson. McGraw-Hill, New York.

Harper, A. E. (1962). Glucose-6-phosphatase. In Methoden der enzymatischen Analyse, p. 788. Ed. by H. U. Bergmeyer. Verlag Chemie, Weinheim.

Havel, R. J., Balasse, E. O., Williams, H. E., Kane, J. P., and Segel, N. (1969). Splanchnic metabolism in von Gierke's disease (glycogenosis type I). Transactions of the Association of American Physicians, 82, 305.

Hers, H. G. (1964). Glycogen storage disease. Advances in Metabolic Disorders, 1, 1.

Howell, R. R., Ashton, D. M., and Wyngaarden, J. B. (1962). Glucose-6-phosphatase deficiency glycogen storage disease: studies on the interrelationships of carbohydrate, lipid, and purine abnormalities. Pediatrics, 29, 553.

Hug, G., and Schubert, W. K. (1967). Serum insulin in type I glycogenosis: effect of galactose or fructose administration. Diabetes, 16, 791.

Huijing, F. (1964). Amylo-1,6-glucosidase activity in normal leucocytes and in leucocytes of patients with glycogen-storage disease. Clinica Chimica Acta, 8, 269.

Huijing, F. (1967). Phosphorylase kinase in leucocytes of normal subjects and of patients with glycogen-storage disease. Biochimica et Biophysica Acta, 148, 601.

Huijing, F., and Fernandes, J. (1969). X-chromosomal inheritance of liver glycogenosis with phosphorylase kinase deficiency. American fournal of Human Genetics, 21, 275.

Kelsch, R. C., and Oliver, W. J. (1969). Studies on dietary correction of metabolic abnormalities in hepatorenal glycogenosis. Pediatric Research, 3, 160.

Lowe, C. U., Sokal, J. E., Mosovich, L. L., Sarcione, E. J., and Doray, B. H. (1962). Studies in liver glycogen disease: effects of glucagon and other agents on metabolic pattern and clinical status. American Fournal of Medicine, 33, 4.

Matschke, I., Neubaur, J., Willms, B., and Wolf, H. (1969). Stoffwechseluntersuchungen bei Kindern und jungen Erwachsenen mit Glykogenosen. Monatsschrift für Kinderheilkunde, 117, 259.

Neubaur, J., Willms, B., Söling, H. D., and Creutzfeldt, W. (1969). Gicht als Komplikation der Glykogenspeicherkrankheit beim Erwachsenen. Archiv für klinische Medizin, 216, 148. 
Peden, V. H. (1964). Determination of individual serum 'ketone bodies' with normal values in infants and children. Fournal of Laboratory and Clinical Medicine, 63, 332.

Rennert, O. M., and Mukhopadhyay, D. (1968). Diazoxide in von Gierke's disease. Archives of Disease in Childhood, 43, 358.

Sidbury, J. B., Jr., Gitzelmann, R., and Fisher, J. (1961). The glycogenoses: further observations on glycogen in erythrocytes of patients with glycogenosis. Helvetica Paediatrica Acta, 16, 506.

Shapiro, B. (1967). Lipid metabolism. Annual Review of Biochemistry, 36, 260.

Snapper, I., and van Creveld, S. (1928). Un cas d'hypoglycémie avec acétonémie chez un enfant. Bulletins et Mémoires de la Société Médicale des Hôpitaux de Paris, 52, 1315.
Sokal, J. E., Lowe, C. U., Sarcione, E. J., Mosovich, L. L., and Doray, B. H. (1961). Studies of glycogen metabolism in liver glycogen disease (von Gierke's disease): six cases with sımilar metabolic abnormalities and responses to glucagon. Fournal of Clinical Investigation, 40, 364.

Trout, D. L., Estes, E. H., Jr., and Friedberg, S. J. (1960). Titration of free fatty acids of plasma : a study of current methods and a new modification. Fournal of Lipid Research, 1, 199.

Correspondence to Dr. J. Fernandes, Sophia Children's Hospital and Neonatal Unit, Gordelweg 160, Rotterdam, The Netherlands.

The following articles will appear in future issues of this journal:

Review Article: The investigation of degenerative disease of the central nervous system. By J. Wilson. Sex differences in childhood urinary tract infections. By T. Bergström.

Daunorubicin: results in childhood leukaemia. By R. N. Matthews and J. H. Colebatch.

66 infants with urinary tract infection in first month of life. By J. M. Littlewood.

Neuronal ceroid lipofuscinosis (Batten's disease). By N. S. Gordon, H. B. Marsden, and M. J. Noronha. Personal Practice: Coeliac disease: some still controversial aspects. By C. M. Anderson, M. Gracey, and V. Burke.

Some problems in surgical management of children with hiatus hernia. By J. Lari and J. Lister.

Aetiological aspects of febrile convulsions: pregnancy and perinatal factors. By S. J. Wallace.

Intrahepatic gas shadows in neonatal duodenal obstruction. By D. G. Shaw.

Quinine intoxication in a child treated by exchange transfusion. By A. W. Burrows, G. Hambleton, M. J. Hardman, and B. D. R. Wilson.

Case of fetus in fetu. By S. P. Lamabadusuriya, A. W. Atukorale, P. E. Soysa, and P. R. Walpeta. 